\title{
Effect of ethylene on physiological and biochemical parameters in different crop plants - A review
}

\section{Kanchan Pahwa* and Navita Ghai}

Department of Botany, Punjab Agricultural University, Ludhiana-141 001 (Punjab), INDIA

*Corresponding author. E-mail: kanchan.pahwa@gmail.com

Received: February 11, 2015; Revised received: July 22, 2015; Accepted: October 4, 2015

\begin{abstract}
A phytohormone may be defined as an organic substance other than a nutrient active in very minute amounts which is formed in certain parts of all plants and which is usually translocated to other sites, where it evokes specific biochemical, physiological and morphological responses. The gaseous plant hormone ethylene modulates many internal processes and growth responses to environmental stimuli. Ethylene is known to exert its effects by altering gene expression both at transcriptional and post-transcriptional level. Ethylene has long been recognized as a growth inhibitor, but evidence is accumulating that ethylene can also promote growth. Therefore, the concept of ethylene as a general growth inhibitor needs reconsideration. Different authors screened various concentrations viz. 100 ppm, 150 ppm which promotes the plant growth in groundnut, soybean, mustard, barley, pigeonpea etc. The lower concentration of ethylene (100ppm) has increased the yield by 17 percent in pigeonpea. It increased the yield by manipulating source-sink relationships and flower retention The present study highlights the various processes of growth stimulated by ethylene and its use in enhancing yield of various crop species. It could be inferred that lower concentration of ethrel sprayed at pre-flowering stage promoted the growth and yield of various crops (barley, corn, groundnut, pigeonpea, soybean etc.).
\end{abstract}

Keywords: Biochemical parameters, Ethrel, Growth, Growth Promoters

\section{INTRODUCTION}

Ethylene belongs to the hydrocarbon group of olefins, which exist in the gaseous state under normal physiological conditions. Its effects on various physiological processes at different stages of plant growth and development have been documented (Khan et al., 2000a). Ethephon is a synthetic plant growth regulator that undergoes chemical biodegradation at $\mathrm{pH}$ greater than 4.1 in cell cytoplasm to release ethylene. The use of ethephon as a growth retardant has been shown for controlling lodging of cereal and grain crops. Ethephon has also been found to impart tolerance against water stress and increasing the productivity of mustard (Brassica juncea L.) (Khan et al., 2000b).

Ethylene is generally considered growth inhibitory with the triple response of dark grown seedlings, first discovered in Pisum sativum, as the classical example. In Arabidopsis, this response consisted of a thickened hypocotyle, inhibition of hypocotyle and root elongation and exaggerated apical hook formation. However, there is increasing number of reports showing ethylene -induced stimulation of growth. Germination, flowering, vegetative development, maturation senescence and response to pathogen are some of the processes for which regulation involves ethylene (Matilla, 2000).

Plant height is an important morphological character. Basically, plant height is a genetically controlled character, but several studies have indicated that plant height is either increased or decreased by the application of synthetic plant growth regulators. Depending upon the plant material and state of development, promotory or inhibitory effects of ethylene on growth have been observed in soybean (Campos et al., 2010) and pigeonpea ( Pahwa et al., 2012).

Reduction in plant height through foliar application of ethrel has been reported in winter wheat (Van Sanford et al., 1989), radish (Vreugdenhil and Harrow, 1989), lupin (Ortuno et al., 1993), arabidopsis (Smalle et al., 1997), barley (Sanvicente et al., 1999), jatropha (Joshi et al., 2011), pigeonpea (Pahwa, 2013). The reduced plant height due to ethrel application might be due to its inhibitory action on auxin transport. Ethylene is an inhibitor of cell division, cell expansion and transport of auxin, which presents expressive effects on the reduction of stem growth in length; however it provides its radial expansion and horizontal orientation (Coll et al., 2001). Joshi et al., (2011) opined that ethylene inhibited stem elongation in whole green plants of jatropha was either by inhibiting basipetal IAA translocation or by affecting IAA metabolism or some other auxin independent action.

Number of branches: Number of branches are indicators of pod bearing capacity of a plant. Pod load establishment is dependent on number of primary 
branches. Improvement in this characteristic is an indicative of pod load establishment. The branches per plant increased due to application of PGRs. This could be the result of increased metabolic and divisional activities in shoot apical meristem. Several physical, genetic and chemical factors are known to exert their influence on meristematic activity in shoot apical meristem. A specific balance of gibberellins, auxins and cytokinins is known to exert their influence on meristematic activity in shoot apical meristem (Taiz and Zeiger, 2006). Maximum increase in number of branches by ethrel treatment might be due to inhibition of apical bud dominance and breaking of lateral bud dormancy (Campos et al., 2010). An increase in ethylene level was observed after removing apical bud in soybean plants, which provided higher cytokinin content to the development of lateral buds and hence increase in number of branches (Tancredi, 2004).

Leaf area: Leaf area is determined by phenology, stem morphology, rates of leaf emergence and potential leaf size. Saxena et al., (2007) also found a significant increase in leaf area at all stages with the application of lower concentration of ethrel. Ethrel when sprayed at pre-flowering stages has a positive effect on cell division leading to enhanced leaf expansion. Leaf area increased with increase in time to a maximum coinciding with maximum top growth and steady decline at later stages (Jirali, 2001). An increase in number of leaves and leaf area per plant of mustard plants following ethephone application was observed by Lone 2001, Mir 2002 and Mir et al., 2009. However, Bhat et al., (2010) reported that lower concentration of ethrel at specific stage promoted expansion of primary leaves, while higher concentration showed a reduction in the area of mustard leaves. Application of ethrel $(100 \mathrm{ppm})$ at pre-flowering stage increased the leaf area in pigeonpea (Pahwa, 2013).

Leaf area index (LAI): Photosynthesis depends upon leaf area index besides the canopy structure and photosynthetic rate. Shekoofa and Emam (2008) reported an increased leaf area index by ethrel treatment in wheat. Mir et al (2008) observed that foliar application of ethephon with $80 \mathrm{~kg} \mathrm{~N} / \mathrm{ha}$ increased LAI, net photosynthesis rate, chlorophyll content and stomatal conductance in brassica. (Devi, 2011) also reported an increase in leaf area index following ethrel application in soybean.

Dry weight: Increase in yield due to growth retardants could be attributed to an increase in partitioning of assimilates towards developing sink. Significant increased dry matter accumulation following ethephon treatment was observed in wheat (Shekoofa and Emam, 2008), mustard (Mir et al., 2008) and pigeonpea (Pahwa et al., 2012).

Crop growth rate (CGR): CGR is a useful growth parameter for estimating the production efficiency of crop stand and it enables to make comparisons between the aspects of study. Increased CGR and NAR indicate the optimum physiological growth of a crop that produces maximum yield. Crop productivity is mainly determined by crop growth rate (CGR) which depends on leaf area index (LAI) and the rate of photosynthesis. The increase in CGR at a particular stage depicts the plant responses to the PGRs at that particular stage and the maximum efficiency of the crop growth can be attained. Increased CGR by growth retardants and promoters sprayed at particular stage was observed by Prabhu (2000). Rahman et al., (2004) concored that increase in CGR due to the application of growth regulators was certainly the result of increase in dry matter production with time course. Karim and Fattah (2007) reported that peak values of CGR were found during pod development stage and foliar application of growth regulators was most effective in increasing CGR as compared to control.

\section{Ethrel and Photosynthetic efficiency}

Chlorophyll content: Pigments such as chlorophylls are needed by plants to absorb sufficient amount of light through photosynthesis. During leaf development, the level of pigments in the leaves increases to provide energy through photosynthesis. Chlorophyll is an important bio-constituent for productivity of the crop plants. Chlorophyll catabolism is the first step of degeneration during senescence but most if not all of enzyme machinery is present in the cell at a basal level before senescence begins. In soybean ethephon delayed the phenological cycle of the crop and maintained high chlorophyll content in the end of the crop cycle, (Campos et al., 2010). The non-degradation of chlorophyll on the tissue maintained them photosynthetically active, thus, providing larger quantity of organic matter to grain filling, leading to the formation of heavier grains, and consequently, increased grain productivity. Similar results in soybean were reported by (Devi, 2011). Significant increase in the chlorophyll content of Brassica napus leaves following ethrel application (500ppm) was reported by Grewal et al., (1993). The exogenous application of ethrel in pigeonpea enhanced chlorophyll synthesis considerably (Pahwa, 2013).

Chlorophyll kinetics: Chlorophyll fluorescence is widely accepted as an indication of the energetic behavior of a photosynthetic system. Photosynthetic activity was studied in terms of quantum yield (Fv/Fm) and total chlorophyll. The Fv/Fm ratio can be considered as a measure of the quantum efficiency of the electron transport in PSII. By measuring the yield of chlorophyll fluorescence, information about changes in the efficiency of photochemistry and heat dissipation can be obtained. Increased chlorophyll fluorescence was observed in leaves of ethrel treated pigeonpea genotypes (Pahwa 2013).

Photosynthesis: The production of biomass and final yield of pulse crops can largely be accounted for by photosynthesis during growth and maturation. It is generally considered that for high yield, high photo- 
synthetic potentials are necessary. Net photosynthesis increased from vegetative to flowering stage and then declined towards maturity. Mir et al (2010) reported that the induction of ethylene biosynthesis might be associated with the application of ethrel, which is a known source of ethylene. This effect of ethrel led to the emergence and formation of leaves with enhanced total leaf area of plant. Higher leaf area resulted in more solar radiation being retained and enhanced net photosynthetic rate $(\mathrm{Pn})$ and total dry matter production. The increase in photosynthesis with ethrel has also been reported both by Pua and Chi (1993) and Khan et al (2000b) in mustard. Exogenous application of ethrel enhanced photosynthesis of Brassica juncea under irrigated and non- irrigated conditions (Khan 2004). The dry matter produced was efficiently translocated towards the developing pods resulting in increase in the seed yield.

Stomatal conductance: Kumar et al (2005) reported that increase in rate of photosynthesis in cotton wasdue to increased stomatal aperture, which facilitate more $\mathrm{CO}_{2}$ conductance. Enhanced stomatal conductance at a range of ethylene concentrations stimulated photosynthesis (Pierik et al 2006). Increased stomatal conductance due to foliar application of ethrel has also been observed in pigeonpea (Pahwa, 2013).

Photosynthetically active radiations: Photsynthetically active radiation (PAR) is a measure of radiation available for photosynthesis. It is well known that plants vary in response to radiations of different wavelengths within the canopy. Mean sunlight irradiance or the proportion of sunlight on leaf surface diminishes as an exponential function of leaf area index. Changes in radiation quantity also occur largely due to the spectral properties of leaf pigments, leading to a reduction in the red/far red ratio as light penetrates the canopy (Guiamet et al., 1989). In this respect there are several evidences that potentiate the climate of canopy change under the influence of growth regulators, which bring about a desirable modification in PAR (Mathias et al., 1989). Grewal and Kolar (1990) in their experiment on Brassica juncea reported that application of ethrel (500, 1000 and 1500ppm) had negative impact on PAR interception, while ethrel application increased the PAR in mustard under non-irrigated conditions (Lone, 2001).

Nutrient uptake: Plant growth regulators are known to influence ion transports and have special effects on membrane properties and functions. Growth regulators have affiliated with reinforcement of assimilate translocation in established sink-source systems (Thomas, 1986; Patrick and Steains, 1987). Desirable increase in the produce of field crops was due to alteration in the trends of assimilate distribution (Addo-Quaye et al., 1986). The allocation of newly fixed carbon in to different metabolic products influenced the partitioning of carbon growth activity of the whole plant (Champigny, 1985). Foliar application of ethrel at the rate of 200 ppm at flower initiation stage increased the uptake of $\mathrm{N}, \mathrm{P}$ and $\mathrm{K}$ in soybean plants (Sing et al., 1987). Ethephon had a strong effect on cultivar $\mathrm{N}$ use efficiency and in particular on the role of $\mathrm{N}$ uptake efficiency in winter wheat (Van Sanford et al., 1989). Use of ethephon resulted in an increased uptake of nutrients in barley (Bulman and Smith, 1993) and Indian mustard (Khan et al., 2000). Under non irrigated conditions ethrel sprayed mustard plants utilized $\mathrm{N}$ from the soil more effectively and showed increased nitrogen harvest index and nitrogen yield merit (Mir, 2002 and Mir et al., 2009c).

\section{Yield and yield attributing parameters}

Pod number/pod set percentage: Solaimalai et al., (2001) observed a significant increase in number of panicles per plant in rice in response to plant growth regulators. They suggested that this increase could have resulted due to enhanced supply of assimilates towards developing reproductive structures. In chickpea, increased pod set percentage due to higher number of pods in treated plants has been observed by Lone (2001). Beneficial effects of ethrel on pod number of mustard has also been reported by (Khan et al., 2000, Mir, 2002 and Mir et al., 2009b). Ethrel improved the pod set percentage in pulses by retaining maximum number of flowers/plant (Saxena et al., 2007). Similar effect of ethylene was observed in pigeonpea by Pahwa (2013).

Seed weight: Foliar application of ethrel at $200 \mathrm{ppm}$ concentration increased 1000 grain weight in soybean (Singh et al., 1987, Saxena et al., 2007). Application at flowering stage of Indian mustard also increased seed weight (Singh and Kumar, 1991). Ethephon application also increased 1000-seed weight in onion (Allium cepa L.) compared to control (Singh et al., 1995). However, Grewal et al., (1993) observed that ethrel treatment resulted in detrimental effect on 1000-seed weight in Brassica napus, while Ramos et al (1989) in barley, Khan et al., (2000); Mir et al., (2008) and Mir et al., (2009 b,c) in mustard, Coffelt and Howell (1986) in pea nut failed to observe any increase in 1000 seed weight in response to the foliar application of ethephon. Pahwa (2013) also reported an increase in seed wight due to foliar application of ethrel at preflowering stage in pigeonpea.

Seed yield: Increase in the seed yield of mustard in response to ethrel has been reported by Grewal et al., (1993); Khan (1996; 1998) and Singh and Kumar (1991). Joshi et al., (1987) also reported increase in seed yield in ground nut (Arachis hypogea L.) when treated with ethrel. Foliar application of ethrel on cauliflower increased the seed yield per plant at 300 ppm while it was adversely affected at higher concentration (Jana and Kabir, 1991). Ethephon treatment significantly increased grain yield in corn (Kasele et al., 1995) and barley (Bulman and Smith, 1993). Saxena et al., (2007) reported that increased seed yield with PGRs has been obtained due to earlier 
retention of more number of flowers and shift in balance of dry matter towards pods thereby favouring the increased pod setting in chickpea. Significantly maximum tuber yield was reported in ethrel treated plants as compared to control (Birbal et al., 2009).

The growth regulators have been found to engage in assimilate translocation towards reproductive parts of plants. Lower concentration of ethrel improved yield of Brassica (Mir et al., 2010) and Pisum sativum (Perry, 2014). Bhat et al., (2010) also reviewed that foliar application of ethrel in various crops improved yield contributing traits viz. number of pods/plant, seed number, 100-seed weight by manipulating source-sink relationship. Devi,(2011) reported that foliar application of ethrel exerted a significant effect on growth of soybean plants when applied at specific time. It increased the yield of soybean by increasing number of retained flowers, pods/plant and 100-seed weight by manipulating source-sink relationship.

Quality parameters: Plant growth regulators have been found to influence significantly the protein content in crop plants (Yang et al., 1994; Kulkarni et al., 1995). They have also been implicated in the control of protein allocation among plant organs and accumulation in developing cereal grains (Oritant and Yoshida, 1971). Soluble proteins increased with the application of ethrel during initial stages of pod development but declined later in ground nut (Arachis hypogea) (Sharma et al., 1982). Grain protein concentration increased (Morris et al., 1989; Van sanford et al., 1989) or remain unaffected (Pearson et al., 1989) by ethephon treatment. Ethrel treatment has been found to increase protein content and efficient incorporation of amino acids into proteins in wheat (Sekhon and Singh, 1994). Ethephon application increased protein content in seeds of pigeonpea genotypes. SDS-PAGE of treated as well as controlled pigeonpea plants showed more dense bands and number of bands were also maximum in treated plants. This indicated that ethrel Sprayed at specific stage promote biochemical changes in pigeonpea (Pahwa, 2013).

Ethrel and anatomical studies: Kaur (1990) observed increase in the diameter of the pedicel of flower with ethrel treatments. The area of the main translocatory tissue i.e. phloem increased significantly in ethrel treated plants. Similar effect of plant growth regulators on translocatory tissue was observed in pigeonpea by Pahwa (2013).

\section{Conclusion}

From the above information it can be inferred that ethylene has not only inhibitory role but it can stimulate the growth of all plants. Its stimulatory action is dose as well as stage dependent. So, the future research can be highlighted upon revealing the internal ethylene levels at various growth stages and manipulating the same via external source so that yield plateau can be achieved in various low yielding crops.

\section{REFERENCES}

Addo-Quaye, A. A., Scarisbrick, D. H. and Daniel, R. W. (1986). Assimilation and distribution of ${ }^{14} \mathrm{C}$ photosynthate in oilseed rape (Brassica napus). Field Crop Res., 13:205-215.

Bhat, M. A., Mir, M.R., Khan, N. A., Lonr, N. A., Bhat, K. A., Razui, S. M., Hayat, S., Payne, W. A., Akhtar, S. and Wani, S. A. (2010). The role of ethrel in plant growth and development under different environmental conditions. Int. J. Curr. Res. 4:4-13.

Birbal, W., Singh, R. K., Kumar, V. and Kushwah, V. S. (2009). Effect of Foliar Application of Plant Growth Regulators on Growth, Yield and Post Harvest Losses of Potato (Solanum tuberosum). Ind. J. Agric. Sci., 79 (9): $1-9$

Bulman, P. and Smith, D. L. (1993). Yield and grain protein response of spring barley to ethephone and triadimefon. Crop Sci., 33:798-803.

Campos, M. F. D., Ono, E. O. and Rodrigues, J. D. (2010). Soybean plant architecture and plant growth regulators application. Pesquisa Aplicada and Agrotechnologia, 3 (1): $161-68$.

Champigny, M. J. (1985). Regulation of photosynthate carbon assimilation at the cellular level: are view. Photosynthesis Res., 6: 273-86.

Coffelt, T. A. and Howell, R. K. (1986). Effect of ethrel seed treatment on growth, yield and grade of two Virginia type peanut cultivars. Peanut Sci., 13: 60-63.

Coll, J. B., Rodrigo, G. N., Garcia, B. S. and Tames, R. S. (2001). Etileno y poliaminas,. In: Coll J B, Rodrigo G N, Garcia B S, Tames R S (Ed.). Fisiologia Vegetal. Madrid: Ediciones Piramide, p. 357-67.

Devi, K. N. (2011). Effect of bioregulators on growth, yield and chemical constituents of soybean (Glycine max). $J$. Agric. Sci., 3 (4):151-159.

Grewal, H. S. and Kolar, J. S. (1990). Response of Brassica Juncea to chlorocholine chloride and ethrel sprays in association with nitrogen application. J. Agric. Sci., 114:87-91.

Grewal, H. S., Kolar, J. S., Cheema, S. S. and Singh, G. (1993). Studies on the use of growth regulators in relation to nitrogen for enhancing sink capacity and yield of gobhisarson (Brassica napus). Ind. J. Plant Physiol., $36: 1-4$.

Guiamet, J. J., Willemoes, G. and Montaldi, E. R. (1989). Modulation of progressive leaf senescence by the red: far-red ratio of incident light. Botanical Gazzette, 150:148-51.

Jana, B. K. and Kabir, K. (1991). Effect of ethrel on seed production of cauliflower $c v$. Dania. Crop Res. 4:222224.

Jirali, D. I. (2001). Physiological investigation in turmeric (Curcuma longa L.). Ph.D. Thesis, University of Agricultural Sciences, Dharwad.

Joshi, G., Shukla, A. and Shukla, A. (2011). Synergistic response of auxin and ethylene on physiology of Jatropha curcas L. Brazilian Society Plant Physiol. 23 (1):67 $-77$.

Joshi, R. K., Mishra, S. D. and Gau, B. K. (1987). Productivity of dormant groundnut as affected by ethrel and benzyladenine. Indian J Agric. Sci., 57: 179-182.

Karim, M. F. and Fattah, Q. A. (2007). Growth analysis of chickpea $c v$. Bari Chhola- 6 as affected by folar sprey of growth regulators. Bangladesh J. Bot., 36 (2):105-10. 
Kasele, I. N., Shanahan, J. F. and Nielson, D. C. (1995). Impact of growth retardents on corn morphology and gas exchangetraits. Crop Sci., 35:190-94.

Kaur, N. (1990). Physiology of assimilates partitioning in relation to yield improvement in pigeonpea (Cajanus cajan L. Millsp.). Ph.D. dissertation. Punjab Agricultural University, Ludhiana, India.

Khan, A., Hatam, M. and Khan, A. (2000a). Heritability and interrelationship among yield determining components of soybean varieties. Pak. J. Agric. Res., 116: 5-8.

Khan, N. A., Lone, N. A. and Samiullah. (2000b). Response of mustard (Brassica juncea L.) to applied nitrogen with or without ethrel spray under non-irrigated condition. $J$. Agron. and Crop Sci., 63-66.

Khan, N. A. (1996). Response of mustard to ethrel spray and basal and foliar application of nitrogen. J. Agron. Crop. Sci., 176: 331-34.

Khan, N. A. (1998). Effect of ethrel spray on yield of mustard cultivars under non-irrigated conditions. Test of Agrochemicals and cultivars, 19:38-39.

Khan, N. A. (2004) An evaluation of the effects of exogenous ethephon, an ethylene releasing compound, on photosynthesis of mustard (Brassica juncea) cultivars that differ in photosynthetic capacity. BMC Plant Biol., 4: 21 .

Khan, N.A., Lone, N.A. and Samiullah. (2000). Response of mustard (Brassica juncea L.) to applied nitrogen with or without ethrel spray under non-irrigated conditions. $J$. Agron. and Crop Sci., 183:1-4.

Kulkarni, S.S., Chetti, M.B. and Uppar, O.S. (1995). Influence of growth retardents on biochemical parameter in sunflower. J. Maharashtra Agric. Uni., 20:352-54.

Kumar, K. A. K., Patil, B. C. and Chetti, M. B. (2005). Effect of plant growth regulators on physiological components of yield in hybrid cotton. Ind. J. Plant Physiol., 10 (2):187-90.

Lone, N. A. (2001). Studies on effect of cycocel and ethrel in association with nitrogen on growth and metabolism of mustard under non-irrigated conditions. PhD Thesis, Aligarh Muslim University, Aligarh, India.

Mathias, J.N., Bradburone, J. A. and Dupree, M. (1989). GA effects on greening in pea seedlings. Plant Physiol., 91:19-22.

Matilla, A. J. (2000). Ethylene in seed formation and germination. Seed Sci. Res., 10:11-126.

Mir, M. R. (2002). Physiological significance of ethrel (2chloroethyl phosphonic acid) and nitrogen in relation to growth and metabolism of mustard under irrigated and non-irrigated conditions. PhD Thesis Aligarh Muslim University, Aligarh, India.

Mir, M. R, Lone, N. A., Khan, N. A., Singh, S., and Asma, H. (2009a). Impact of ethrel and nitrogen on growth, leaf water content, potassium accumulation and dry mass of mustard (Brassica juncea L.). SKUAST J. Res., 11:187-192.

Mir, M. R., Khan, N. A., Rather, G. H., Lonem, N. A. and Subaya, B. (2008). Effect of nitrogen and ethrel on various physiological and yield attributes of mustard (Brassica juncea L.). Applied Biol. Res., 10:1-5.

Mir, M. R., Khan, N.A., Bhat, M.A., Lone, N.A., Rather, G. H., Rajvi, S. M., Bhat, K. A., Singh, S. and Payne, W. A. (2010). Effect of ethrel spray and nitrogen on growth, photosynthesis, carboxylation efficiency and water use efficiency of mustard (Brassica juncea L.). Intl. J. Curr. Res., 6:45.52.
Mir, M. R., Lone, N. A. and Khan, N. A. (2009b). Impact of exogenously applied ethephon on physiological and yield attributes of two mustard cultivars under rainfed conditions. Applied Biol Res., 11:44-46.

Mir, M.R., Khan, N. A., Lone, N. A., Payne, W. A., Mir, A. H., Asma, H. and Viqar, A. (2009c). Effect of basal nitrogen application and foliar ethephon spray on morphophysiology and productivity of mustard (Brassica juncea L.). Applied Biol. Res., 11:60-65.

Morris, C. F., Ferguson, D. L. and Paulsen, G. M. (1989). Nitrogen fertilizer management with foliar fungicide and growth regulator for hard winter wheat production. Applied Agronomical Res., 4:135-40.

Oritant, T. and Yoshida, R. (1971). Studies on nitrogen metabolism in crop plants XI. The change in abscisic acid and cytokinin like activity accompanying with growth and senescence in the crop plants. Proc. Crop Sci. Society of Japan, 40:325-31.

Ortuno, A. J. A., Del, R. J. L., Cases, M., Serrao, M. A. and Sanchez-Brava, J. (1993). Influence of ACC and ethephone on cell growth in etiolated lupin hypocotyls; dependence on cell growth stage. Biologia Plantarum .33:81-91.

Pahwa, K. (2013). Effect of plant growth regulators on manipulation of source-sink relationships in pigeonpea. Ph.D. dissertation. Punjab Agricultural University, Ludhiana, India.

Pahwa, K., Ghai, N., Kaur, J., and Singh, S.(2012). Effect of some growth regulators on flower drop and yield of pigeonpea. Special issue Crop Improvement pp. 175-76.

Patrick, J. W. and Steains, K. H. (1987). Auxin promoted transport of metabolites in stem of phaseolus vulgare: auxin dose response curves and effect of inhibitors of polar auxin transport. J. Exp. Bot., 38:203-210.

Pearson, C. H., Golus, H. M. and Tindall, T. A. (1989). Ethephon application and nitrogen fertilization of irrigated winter barley in an arid environment. Agron. J., 81:717-19.

Perry, G.( 2014). Ethylene induced soil microbes to increase seed germination, reduce growth time and improve crop yield in Pisum sativum L. Peerj Preprints, 2-18.

Pierik, R., Tholen, D., Poorter, H., Visser, E. J. W. and Voesenek, L. A. C. J. (2006). The Janus face of ethylene: growth inhibition and stimulation. Trends Plant Sci., 11: 176-83.

Prabhu, D. (2000). Influence of plant growth regulators and micronutrients in blackgram (Vigna mungo). M. Sc. (Agri.) Thesis, University of Agricultural Sciences, Dharwad.

Pua, E. C. and Chi, G. L. (1993). De novo shoot morphogenesis and plant growth of mustard (Brassica juncea) in vitro in relation to ethylene. Physiol. Plant, 88: 467 -474 .

Rahman, M. S., Islam, N., Tahar, M. A. and Karim, M. A. (2004). Influence of $\mathrm{GA}_{3}$ and $\mathrm{MH}$ and their time of spray on dry matter accumulation and growth attributes of soybean. Pak. J. Biol. Sci., 7(11): 1851-57.

Ramos, J. M., Garcial, M. L. F., Molina-cano, J. L., Salamanca, P. and Roca, T. F. (1989). Effect of an early application of sulpher or ethephon as foliar sprays on the growth and yield of spring barley in a Mediterranean environment. Agron. Crop Sci., 163:129-37.

Sanvicente, P., Lozarevitch, S., Brouet, A. and Guckert, A. (1999). Morphological and Anatomical modification in winter barley culm after late plant growth regulator 
treatment. European J. Agron., 11:45-51.

Saxena, D. C., Abbas, S. and Sairam, R. K. (2007). Effect of ethrel on reproductive efficiency in chickpea. Indian $J$. Plant Physiol., 12(2):162-67.

Sekhon, N.K. and Singh, G. (1994). Effect of growth regulators and date of sowing on grain development in wheat. Indian J. Plant Physiol., 37:1-4.

Sharma, R., Sharma, B. and Singh, G. (1982). Effect of growth regulators on on some biochemical changes during pod development in ground-nut (Arachis hypogea). Indian J. Bot., 5:102-106.

Shekoofa, A. and Emam, Y. (2008). Plant growth regulator (ethephon) alters maize (Zea mays L.) growth, water use efficiency and grain yield under water stress. $J$. Agron., 7(1):41-48.

Singh, H., Chandra, S., Jolly, R.S. and Kolar, I. S. (1987). Influence of chlorocholine chloride and ethrel on grain yield and uptake of nitrogen, phosphorus and potassium in soybean. Crop Improv., 14:79-83.

Singh, R. P. and Kumar, A. (1991). Effect of phytohormones on yield attributes and seed yield of mustard (Brassica Juncea). Indian J. Agron., 36:379-81.

Singh, S., Singh, K. and Singh, S. P. (1995). Effect of hormones on growth and yield characters of seed crop of kharif onion (Allium cepa L.). Indian J. Plant Physiol., 38:193-96.

Smalle, J., Heagman, M., Kurepa, J., Van, M. M. and Van,
D. S. D. (1997). Ethylene can stimulate Arabidopsis hypocotyles elongation in light. Proc. of the National Academy of Sci. of the United States of America., 94: 2756-61.

Solaimalai, A., Sivakumar, C., Anbumani, S., Suresh, T. and Arulmurugan, K. (2001). Role of plant growth regulators in rice production-a review. Agric. Rev., 22 (1) :3340.

Taiz, L. and Zeiger, E. (2006). Plant Physiology. 4.ed. Sunderland: Sinauer Associates, Inc. Publishers, 700 p.

Tancredi, F. D. (2004). Influência da remoção do meristema apical sobre os componentes de produtividade em populações de plantas de soja. Acta Scientiarum Agronomy, 26(1): 113-119.

Thomas, T. H. (1986). Hormonal control of assimilate movement and compartmentation. In: Plant Growth Substances. Pp. 350-359. M. Bopp (Ed.). Springer-Verlag, Heidelberg.

Van Sanford, D.A., Grove, J. H., Grabau, J. and Mackown, C. T. (1989). Ethephon and nitrogen use in winter wheat. Agronomy J., 81:951-54.

Vreugdenhil, D. and Harro, J. B. (1989). Effects of ethylene on tuberization in radish (Raphinus sativus). Plant Growth Regulators, 8:21-30.

Yang, D. Q., Yang, J. X. and Hu, Y. W. (1994). Effects of S3307 on some physiological characteristics of rape seedlings. Plant Physiol. Commun., 30:182-85. 